\title{
Protein composition of yak milk
}

\author{
Haimei $\mathrm{LI}^{1}$, Ying $\mathrm{MA}^{1 *}$, Aijun Dong ${ }^{1}$, Jiaqi $\mathrm{WANG}^{2}$, Qiming $\mathrm{Lr}^{2}$, Shenghua $\mathrm{HE}^{1}$, \\ Jean-Louis MAUBOIS ${ }^{3,4}$ \\ ${ }^{1}$ School of Food Science and Engineering, Harbin Institute of Technology, Harbin 150090, P.R. China \\ ${ }^{2}$ Research and Development Central of New Hope Dairy Company, Chengdu 610041, P.R. China \\ ${ }^{3}$ INRA, UMR1253, F-35042 Rennes, France \\ ${ }^{4}$ AGROCAMPUS OUEST, UMR1253, F-35042 Rennes, France
}

Received 10 August 2009 - Revised 28 October 2009 - Accepted 29 October 2009

Published online 17 December 2009

\begin{abstract}
The protein composition of 24 individual Maiwa yak milk samples that were collected in the Sichuan province of China was determined by reversed-phase high-performance liquid chromatography. Yak milk differed from cow milk by its high concentration of total proteins (46.2$\left.58.4 \mathrm{~g} \cdot \mathrm{L}^{-1}\right)$, total casein $\left(40.2 \mathrm{~g} \cdot \mathrm{L}^{-1}\right.$ on average) and the proportion of individual caseins. The high content of $\beta$-casein (more than 45\%) and consequently the lower proportion of $\alpha_{\mathrm{s}}$-casein (about $40 \%)$ together with a small increase in $\kappa$-casein $(15 \%)$ appear to make this milk more favorable for infant nutrition as used by the Tibetan nomads. Also, the whey proteins, $\beta$-lactoglobulin and serum albumin, showed similarities in centesimal composition with the homologous cow whey proteins. However, this initial study on yak milk proteins has highlighted the lack of knowledge in the literature and underlines that much research is required to optimize the utilization of all components of this milk for people living in extreme climatic environments.
\end{abstract}

yak milk / casein / whey protein / HPLC

摘要 - 牦牛乳的蛋白质组成。采用 RP-HPLC 方法, 对中国四川省麦洼地区的 24 个牦牛乳 样品蛋白质的组成进行了分析。牦牛乳与牛乳相比, 在总蛋白质含量 $\left(46.2-58.4 \mathrm{~g} \cdot \mathrm{L}^{-1}\right)$ 、总 酪蛋白质含量 $\left(40.2 \mathrm{~g} \cdot \mathrm{L}^{-1}\right)$ 和各酪蛋白在总酪蛋白所占的比例方面都存在较大的差异。牦牛 乳中 $\beta$-酪蛋白在总酪蛋白中的含量很高 (大于 $45 \%$ ), 而 $\alpha_{\mathrm{s}}$-酪蛋白约占总酪蛋白的 $40 \%$, $\kappa$-酪 蛋白约占总酪蛋白的 $15 \%$ 。牦牛乳酪蛋白的组成非常适合婴幼儿的营养需要, 中国西藏少数 民族地区的人们也通常用牦牛乳来哺育婴幼儿。牦牛乳中 $\beta$-乳球蛋白和血清白蛋白的组 成与牛乳相似。目前关于牦牛乳蛋白质组成方面的知识及可参考的文献非常少, 并且为了 使生活在极端环境条件下的人们能更好地开发利用牦牛乳, 应该加强并深入对牦牛乳的 研究。

\section{牦牛乳 / 酪蛋白 / 乳清蛋白 / 高效液相色谱}

Résumé - Composition protéique du lait de yak. La composition protéique de 24 échantillons de lait de yak de race Maiwa, collectés dans la province de Sichuan en Chine, a été déterminée par chromatographie liquide haute performance. Par rapport au lait de vache, le lait de yak présentait des teneurs nettement plus élevées en protéines totales $\left(46.20-58.40 \mathrm{~g} \cdot \mathrm{L}^{-1}\right)$ et en caséine $\left(40.2 \mathrm{~g} \cdot \mathrm{L}^{-1}\right.$ en moyenne). Les différences portaient aussi sur la proportion des caséines individuelles, la caséine $\beta$ représentant plus de $45 \%$ de la caséine entière, la caséine $\alpha_{\mathrm{s}}$, environ $40 \%$ et la

*Corresponding author (通讯作者): maying@hit.edu.cn 
caséine $\kappa$, environ $15 \%$. Ces proportions proches de celles existant dans la caséine du lait humain sont probablement la raison de la consommation usuelle de ce lait par les nourrissons des nomades tibétains. Les déterminations des protéines solubles également réalisées dans le cadre de cette étude montraient une forte similarité de composition en $\beta$-lactoglobuline et sérum albumine par rapport aux protéines homologues du lait de vache. Ces premiers résultats sur les protéines du lait de yak mettent en évidence la faiblesse des connaissances disponibles sur ce sujet et a contrario l'effort de recherches qui se doit d'être réalisé pour une utilisation la mieux adaptée possible des composants de ce lait aux besoins des populations vivant dans un environnement climatique extrême.

lait de yak / caséine / protéine de lactosérum / HPLC

\section{INTRODUCTION}

Yak (Bos grunniens) milk has a high content of total solids (16.9-17.9\%), proteins $(4.9-5.9 \%)$ and fat $(5.5-7.5 \%)$ $[13,14]$. These values are significantly higher than those of cow (Bos taurus) and goat (Capra hircus) milk, but relatively similar to those of buffalo (Bubalus bubalis) and ewe (Ovis aries) milk [13]. Like in most of the other mammalian milks, proteins of yak milk mainly consist of the four individual caseins $\left(\alpha_{\mathrm{s} 1}-\mathrm{CN}, \alpha_{\mathrm{s} 2}-\mathrm{CN}, \beta-\mathrm{CN}\right.$ and $\kappa-\mathrm{CN}$ ) and the major whey proteins ( $\alpha$-lactalbumin, $\beta$-lactoglobulin, serum albumin (SA), lactoferrin and immunoglobulins) [11]. Although the polymorphism of yak milk proteins has been studied in the past [3] and more recently [10], a very few literature is available, and the results on the average content of each individual protein in bulk yak milk are often contradictory $[8,11]$. In recent years, there has been a significant increase in the yak population in China, despite the difficulties in their husbandry. These cattle are used to living in an extreme climatic environment such as in Tibet and the surrounding areas. Due to the increase in yak milk production, a deeper knowledge and understanding of the biochemical compounds of this product is required in order to develop novel products other than the more traditional ones [14]: butter, fermented skimmed and whole milk, and Qula (a kind of traditional acid curd). Moreover, to fully realize the nutritional value of yak milk, all the usual transformation technologies used in the production of consumer milks, yoghurts, cheese, powders, etc., cannot be optimized without this knowledge. Hence, the objective of this study was to analyze the protein composition of Maiwa yak milk using RP-HPLC, and using purified individual caseins and whey proteins of known genotypes as standards.

\section{MATERIALS AND METHODS}

\subsection{Yak milk samples}

Twenty-four individual Maiwa yak milk samples, representative of a complete milking of the animals that were in the middle of their lactation period, were collected from the Sichuan province in China. After addition of sodium azide $\left(0.4 \mathrm{~g} \cdot \mathrm{L}^{-1}\right)$, the milk samples were immediately frozen at $-20{ }^{\circ} \mathrm{C}$ and transported to the laboratory. Total protein contents were analyzed by the Kjeldahl method [4].

\subsection{Sample preparation}

Standard bovine caseins and whey proteins were purchased from Sigma: $50 \mathrm{mg} \mathrm{\kappa -CN} \mathrm{(lot} \mathrm{C-0406,} \mathrm{purity} \mathrm{>} \mathrm{80 \% ),}$ $125 \mathrm{mg} \quad \alpha_{\mathrm{s}}-\mathrm{CN}$ (lot C-6780, purity $>85 \%$ ), $50 \mathrm{mg} \beta-\mathrm{CN}$ (lot C-6950, purity $>90 \%$ ), $10 \mathrm{mg} \alpha$-La (lot L-5385 type I, purity $>85 \%$ ), $\quad 15 \mathrm{mg} \quad \beta-\operatorname{LgB} \quad$ (lot 
L-8005), $10 \mathrm{mg} \beta$-LgA (lot L-7880) and $50 \mathrm{mg}$ BSA were dissolved in $5 \mathrm{~mL}$ buffer solution $\left(8 \mathrm{~mol} \cdot \mathrm{L}^{-1}\right.$ urea, $165 \mathrm{mmol} \cdot \mathrm{L}^{-1}$ Tris, $44 \mathrm{mmol} \cdot \mathrm{L}^{-1}$ sodium citrate and $0.3 \%(\mathrm{v} / \mathrm{v})$ $\beta$-mercaptoethanol).

Samples were thawed using flowing tap water prior to analysis. The fat was removed by centrifugation at $1000 \times \mathrm{g}$ for $10 \mathrm{~min}$ at $4{ }^{\circ} \mathrm{C}$. One milliliter of skimmed milk was dissolved in $4 \mathrm{~mL}$ of buffer solution. The diluted samples were filtered through a $0.45 \mu \mathrm{m}$ cellulose membrane (A-FIT Biosciences Ltd., Beijing, China) and directly analyzed. All samples were analyzed in triplicate.

\subsection{RP-HPLC of milk samples}

Reversed-phase HPLC analyses were performed on a Jupiter $\mathrm{C} 4$ column $(250 \mathrm{~mm} \times$ $4.6 \mathrm{~mm}, 300 \AA$ sized pores, $5 \mu \mathrm{m}$ sized particles; Phenomenex, Torrance, CA, USA). The detection wavelength used was $220 \mathrm{~nm}$. The HPLC equipment consisted of an Agilent 1100 Series chromatograph (Agilent Technologies, Santa Clara, CA, USA) equipped with a quaternary pump (Agilent 1100 Series, G1311A). A variable wavelength ultraviolet detector (Agilent 1100 Series, GB15 A/B, DAD) was used. The equipment was controlled by the Agilent ChemStation for LC Systems software that controlled solvent gradient, data acquisition and data processing. The analyses were carried out by applying a binary gradient profile of the mobile phase. Solvent A was ultrapure water containing $0.1 \%(\mathrm{v} / \mathrm{v})$ trifluoroacetic acid (TFA), and solvent B was HPLC-grade acetonitrile containing $0.1 \% \quad(\mathrm{v} / \mathrm{v})$ TFA (concentration of acetonitrile $\geq 99.9 \%$ ). The gradient elution program was run at a constant flow rate of $1.0 \mathrm{~mL} \cdot \mathrm{min}^{-1}$ and was set as follows: $0-40 \mathrm{~min}$ linear gradient from $30 \% \mathrm{~B}$ to $50 \% \mathrm{~B} ; 40-42$ min linear gradient from $50 \% \mathrm{~B}$ to $100 \% \mathrm{~B}$; $42-43 \mathrm{~min}$ isocratic elution $100 \% \mathrm{~B}$; 43-46 min linear gradient from $100 \% \mathrm{~B}$ to $30 \% \mathrm{~B}$, followed by a 5-min isocratic elution at the initial conditions. The total duration of a single run, including column equilibration, was $60 \mathrm{~min}$ [1]. The temperature of the column was kept at $30{ }^{\circ} \mathrm{C}$.

Casein contents were determined by summation of the data obtained through RP-HPLC for the four individual caseins after verification that these values were in agreement with those obtained by classical precipitation at $\mathrm{pH} 4.6$.

\section{RESULTS AND DISCUSSION}

\subsection{Identification of caseins and whey proteins in yak milk}

A characteristic RP-HPLC profile of yak milk proteins is presented in Figure 1. All proteins were efficiently separated. Comparison with the profile obtained with standard cow milk proteins allowed the identification and quantification of the four individual caseins and the main whey proteins, $\beta$-LgA, $\beta$-LgB, $\alpha$-La and BSA. As it had been previously shown for cow $\kappa-\mathrm{CN}$, the Maiwa yak casein chromatogram shows three or four peaks for this casein indicating not only the genetic variation described on the gene CSN3 by Prinzenberg et al. [10], but also several possible degrees of glycosylation [12]. To quantify the $\kappa-\mathrm{CN}$, the three or four peaks (Fig. 1) were summed to give the total $\kappa$-casein value indicated in Table I. Because cow $\alpha_{\mathrm{s} 1}-\mathrm{CN}$ and $\alpha_{\mathrm{s} 2}-\mathrm{CN}$ were not available as individual proteins, the corresponding values for homologous yak caseins were determined from the $\alpha_{\mathrm{s}}-\mathrm{CN}$ calibration obtained by applying the $4: 1$ proportion known for bovine milk [1]. Regarding $\beta-\mathrm{CN}, 15$ individual Maiwa yak milk samples showed only one $\beta$-casein peak but for nine other Maiwa yak milk samples, two $\beta$-casein fractions were partially separated. These results indicate that a polymorphism of this individual casein is likely. However, this hypothesis disagrees with Mao et al. [7] 


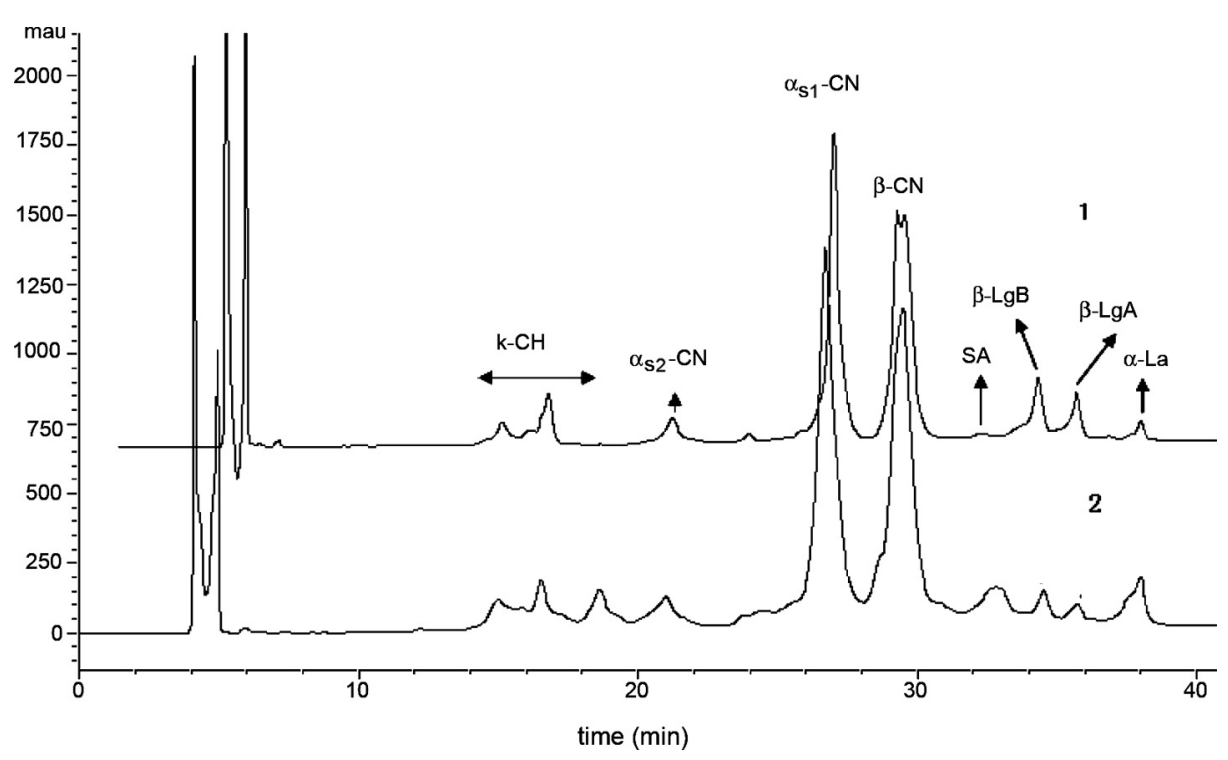

Figure 1. Chromatograms of standard bovine milk proteins and skimmed yak milk (1, skimmed yak milk and 2, standard bovine milk). Column: Phenomenex Jupiter $\mathrm{C}_{4}(250 \mathrm{~mm} \times 4.6 \mathrm{~mm}$, $300-\AA$ pores, $5 \mu \mathrm{m}$ particles); UV, $\lambda=220 \mathrm{~nm}$; mobile phase: water containing $0.1 \%$ TFA/acetonitrile containing $0.1 \%$ TFA.

who reported that $\beta$-casein was monomorphic but is in agreement with the hypothesis of Prinzenberg et al. [10]. As for most of the mammalian milks, yak milk caseins show a complex qualitative genetic polymorphism. Further research must be done to improve knowledge in this field for many purposes such as possible relationships with milk production [11], heat stability, and manufacturing properties [13].

\subsection{Protein distribution in yak milk}

Table I summarizes the data of individual and total casein determined on the 24 samples of collected yak milks. Total casein content of yak milk (40.2 $\mathrm{g} \cdot \mathrm{L}^{-1}$ on average) is 1.5 times the concentration of cow milk [13] and 11 times that of human milk [6]. Besides having high levels of casein that had been reported previously [13], the results of this study indicate that there is also a high proportion of $\beta-\mathrm{CN}$ (more than $45 \%$ on average and ranging from $37.18 \%$ to $51.16 \%$ ), which, to our knowledge, has not previously been described in the literature. This high level of $\beta-\mathrm{CN}$ is thought to result in a smooth and soft coagulum in the stomach, which is easily digested by the enzymes of the intestinal tract. This perhaps explains why yak milk is usually given, after dilution, to babies by Tibetan nomads to complement breast milk [14]. On the other hand, it would be interesting to determine the sequence of yak $\beta-\mathrm{CN}$ to elucidate whether the bioactive peptides $\beta-\mathrm{CN} 1-25,60-65,177-183$, etc. are present and have the same physiological abilities as their homologous sequences in human and cow $\beta-\mathrm{CN}$ [5]. Also, the high proportion of $\beta-\mathrm{CN}$ and, consequently, the lower proportion of $\alpha_{\mathrm{s}}-\mathrm{CN}$ (about $40 \%$ for 
Table I. Mean concentration of casein fractions in Maiwa yak milk.

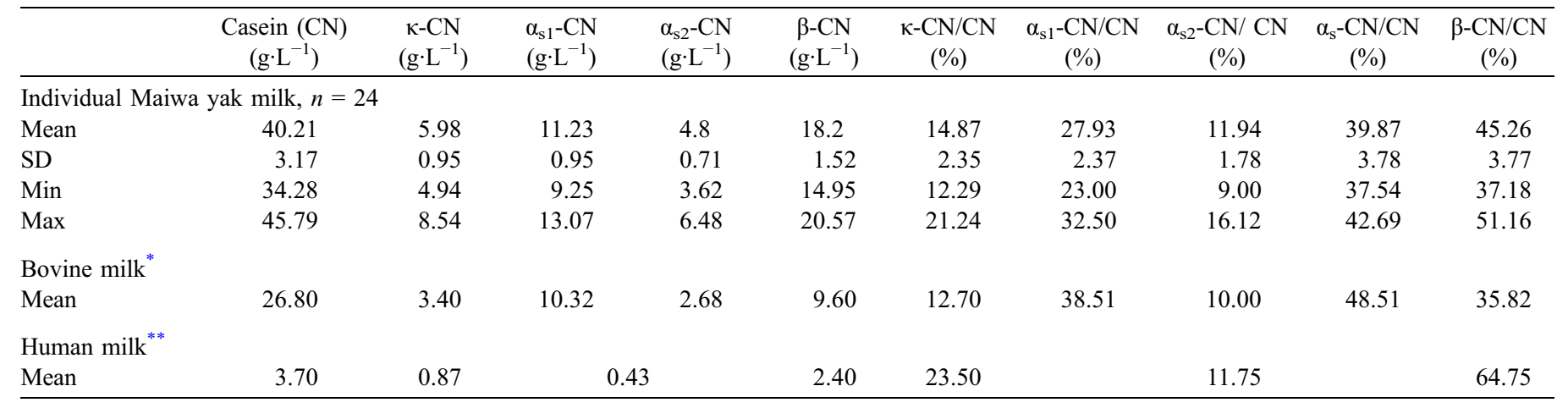

* Reference to bovine milk: Walstra et al. [13]

${ }^{* *}$ Reference to human milk: Malacarne et al. [6]. 
Table II. Mean concentration of whey protein fractions in Maiwa yak milk.

\begin{tabular}{lcccccccc}
\hline $\begin{array}{c}\text { Total protein (TP) } \\
\left(\mathrm{g} \cdot \mathrm{L}^{-1}\right)\end{array}$ & $\begin{array}{c}\alpha-\mathrm{La} \\
\left(\mathrm{g} \cdot \mathrm{L}^{-1}\right)\end{array}$ & $\begin{array}{c}\beta-\mathrm{LgA} \\
\left(\mathrm{g} \cdot \mathrm{L}^{-1}\right)\end{array}$ & $\begin{array}{c}\beta-\mathrm{LgB} \\
\left(\mathrm{g} \cdot \mathrm{L}^{-1}\right)\end{array}$ & $\begin{array}{c}\mathrm{SA} \\
\left(\mathrm{g} \cdot \mathrm{L}^{-1}\right)\end{array}$ & $\begin{array}{c}\alpha-\mathrm{La}-/ \mathrm{TP} \\
(\%)\end{array}$ & $\begin{array}{c}\beta-\mathrm{Lg}(\mathrm{A}+\mathrm{B}) / \mathrm{TP} \\
(\%)\end{array}$ & $\begin{array}{c}\mathrm{BSA} / \mathrm{TP} \\
(\%)\end{array}$ \\
\hline Individual Maiwa & yak milk, $n=24$ & & & & & & & \\
Mean & 52.50 & 0.72 & 0.74 & 5.49 & 1.49 & 1.37 & 11.87 & 2.84 \\
SD & 0.30 & 0.39 & 0.26 & 1.44 & 1.23 & 0.75 & 3.05 & 2.35 \\
Min & 46.20 & 0.22 & 0.30 & 3.08 & 0.23 & 0.42 & 6.44 & 0.44 \\
Max & 58.40 & 1.68 & 1.32 & 8.89 & 3.07 & 3.20 & 19.44 & 5.85 \\
Bovine milk & & & & & & & & \\
Mean & 34.20 & 1.24 & 3.30 & 0.41 & 3.70 & 9.80 & 1.20 \\
\hline
\end{tabular}

*References to bovine milk: Walstra et al. [13].

yak milk vs. $49 \%$ for bovine milk) together with a small increase of $\kappa-\mathrm{CN}(15 \%$ compared to $12 \%$ for bovine milk) will influence the usefulness of yak milk for cheese making (renneting time, final firmness of the curd, whey drainage, etc.). More research is needed for an in-depth characterization of yak casein micelles properties, such as size distribution, $\xi$ potential and mineralization.

Table II summarizes the results of whey protein determinations. The few data available in the literature concerning whey proteins in yak milk strongly limit a discussion of these data. Indeed, Ochirkhuyag et al. [9] have identified the amino acid composition of the main whey proteins, $\beta$-lactoglobulin and $\alpha$-lactalbumin, but they did not give the content of these proteins. However, comparison with cow whey proteins shows that the proportion of total $\beta$ - $\mathrm{Lg}$ in total proteins appears to be in the same range in yak milk. On average, there were a higher proportion of SA in yak milk compared to cow milk, but the individual variations were high. The value found for $\alpha$-La is puzzling because it is not in line with the usual relationship between lactose and $\alpha$-La contents in mammalian milks [2]. Indeed, $\alpha$-La is half of the lactose synthetase enzyme [2] and its content increases with lactose concentration. In the collected samples of yak milk, the lactose concentrations $\left(50.1-59.2 \mathrm{~g} \cdot \mathrm{L}^{-1}\right)$ were higher than that of bovine milk.

\section{CONCLUSION}

In conclusion, as previously mentioned for the casein group, there is a huge lack of knowledge on the whey proteins of yak milk. Further in-depth research is required both for nutritional purposes (major and minor whey proteins are now known to play an essential physiological role in immune defense, brain development, bone mineralization, etc. [5]) and for a better and complete utilization of milk yak components by the dairy industry. Also, the acquired knowledge would allow the development of new diversified beneficial products adapted to the needs of people living in extreme climatic environments.

Acknowledgements: This study was founded by National Natural Science Foundation of China and by the society ISDP. Both organizations are warmly thanked for their help.

\section{REFERENCES}

[1] Bonizzi I., Buffoni J.N., Feligini M., Quantification of bovine casein fractions by direct chromatographic analysis of milk. 
Approaching the application to a real production context, J. Chromatogr. A. 1216 (2009) 165-168.

[2] Fox P.F., McSweeney P.L.H., Nutritional aspects of milk proteins, in: Fox P.F. (Ed.), Advanced Dairy Chemistry, Vol. 1: Proteins, Academic Press/Plenum Publishers, New York, USA, 2003, p. 625.

[3] Grosclaude F., Mahé M.-F., Accolas J.-P., Note sur le polymorphisme des lactoprotéines de bovins et de yaks Mongols, Ann. Génét. Sél. anim. 14 (1982) 545-550.

[4] Horwitz W., Official Methods of Analysis of AOAC International, AOAC International, Maryland, USA, 2000, chapter 33, p. 10.

[5] Léonil J., Bos C., Maubois J.-L., Tomé D., Protéines, in: Debry G. (Ed.), Lait, nutrition et santé, Tec \& Doc Lavoisier, Paris, France, 2001, pp. 45-84.

[6] Malacarne M., Martuzzi F., Summer A., Mariani P., Protein and fat composition of mare's milk: Some nutritional remarks with reference to human and cow's milk, Int. Dairy J. 12 (2002) 869-877.

[7] Mao Y.J., Zhong G.H., Zheng Y.C., Peng X.W., Yang Z.P., Wang Y., Jiang M.F., Genetic polymorphism of milk protein and their relationships with milking performances in Chinese yak, Sci. Agric. Sinica 3 (2004) 310-315.

[8] Ochirkhuyag B., Chobert J.M., Dalgalarrondo M., Choiset Y., Haertlé T., Characterization of caseins from Mongolian yak, khainak and bactrian camel, Lait 77 (1997) 601-613.

[9] Ochirkhuyag B., Chobert J.-M., Dalgarrondo M., Choiset Y., Haertlé T., Characterization of whey proteins from Mongolian yak, khainak and bactrian camel, J. Food Biochem. 22 (1998) 105-124.

[10] Prinzenberg E.M., Jianlin H., Erhardt G., Genetic variation in the $\kappa$-casein gene (CSN3) of the Chinese yak (Bos grunniens) and phylogenetic analysis of CNS3 sequences in the genius Bos, J. Dairy Sci. 91 (2008) 1198-1203.

[11] Sheng Q., Li J., Alam M.S., Fang X., Guo M., Gross composition and nutrient profiles of Chinese yak (Maiwa), Int. J. Food Sci. Technol. 43 (2008) 568-572.

[12] Swaisgood H.F., Chemistry of caseins, in: Fox P.F. (Ed.), Advanced Dairy Chemistry, Vol. 1: Proteins, Elsevier Publishers, New York, USA, 1992, pp. 63-110.

[13] Walstra P., Geurts T.J., Noomen A., Jellema A., van Boekel M.A.J.S., Dairy Technology, Publisher Marcel Dekker, New York, USA, 1999.

[14] Wiener G., Jianlin H., Ruijun L., The yak, Regional Office for Asia and the Pacific, Food and Agriculture Organisation of the United Nations, 2003. 